\title{
Novel Facets and Challenges in the Management of Phytopathogens Using Myconanoparticles
}

\author{
R.N. Yadav", M.K. Chitara ${ }^{2}$, N.W. Zaidi ${ }^{3 *}$, A.I. Khan ${ }^{4}$, U.S. Singh ${ }^{3}$ and H.B. Singh ${ }^{1}$ \\ ${ }^{1}$ Department of Mycology and Plant Pathology, Institute of Agricultural Sciences, Banaras \\ Hindu University, Varanasi- 221005, India \\ ${ }^{2}$ Department of Plant Pathology, Govind Ballabh Pant University of Agriculture and \\ Technology, Pantnagar, Uttrakhand-263145, India \\ ${ }^{3}$ IRRI-South Asia Regional Centre, Varanasi - 221005, India \\ ${ }^{4}$ International Rice Research Institute, NARC Building, Singha Durbar Plaza, \\ Kathmandu, Nepal \\ *Corresponding author
}

\begin{tabular}{|l|}
\hline Ke y w o r d s \\
Myconanoparticles, \\
$\begin{array}{l}\text { Toxicity, Silver } \\
\text { nanoparticles, Disease } \\
\text { diagnosis, Biosynthesis }\end{array}$ \\
\hline Article Info \\
\hline $\begin{array}{l}\text { Accepted: } \\
\text { 24 September } 2018 \\
\text { Available Online: } \\
\text { 10 December } 2018\end{array}$ \\
\hline
\end{tabular}

\section{A B S T R A C T}

Nanotechnology is an interdisciplinary having significant role in modern science. Myconanotechnology is an emerging field, where fungi are being used for the synthesis of nanoparticles with desirable size and shape. Fungi have an added advantage over bacteria as well as actinomycetes, as fungi are excellent secretors of proteins leads to a higher yield of nanoparticles which are highly stable, cost-effective, eco-friendly and non-toxic. Currently, a wide range of potential fungi are being screened to create different nanoparticles, such as silver, selenium, platinum, gold, silica, zirconium, zinc oxide, copper, titanium, chitosan, and magnetite had also been reported by various researchers. Mycogenic nanoparticles in phytopathogen management are still in early stage of research. Nowadays due to climate change, farming communities are facing major challenges such as emergence of new diseases and pest, nutrient deficiency, thereby reducing the crop yield. Nearly 2.5 metric tons of chemical pesticides are used annually for the management of various diseases and pests, these chemicals are toxic for both soil and aerial environment. Moreover, mycogenic nanoparticles are non-toxic, possess excellent antimicrobial properties, and have a wide range of applications for plant disease and pest management, enhanced nutrient uptake and improved plant growth. Different experiments have revealed that fungal hyphae and conidial germination of pathogenic fungi are inhibited by mycogenic silver selenium and copper nanoparticles. These myconanoparticles can be used for accurate disease diagnosis and also for its eco-friendly management. The progress towards the development of nano-herbicides, nano-fungicides and nano-pesticides will open-up new avenues in the field of integrated crop management. However some challenges particularly toxicity, which is not a big issues as compare to chemical fungicides and pesticides are hindering the commercialization of myconanoparticles in plant disease management. 


\section{Introduction}

Agriculture is the chief interface between humans and the environment and is a key cause of soil and ecosystem modification. Despite the widespread appliance of chemicals, direct yield losses caused by pathogens, animals, and weeds, are overall responsible for losses ranging between 20 and $40 \%$ or even over $50 \%$ of global agricultural productivity. The amelioration of intensification of agricultural production was halted by the evolution of resistance opposed to pesticides in pest populations. Such resistance comprising to several combinations of pesticides has been reported by now, and post-harvest pathogens can also develop multiple pesticide resistance (Juric et al., 2017).

In green nanotechnology, for the synthesis of nanoparticles (NPs) microorganisms are used. It is well recognized that many microorganisms aggregate inorganic material within or outside the cell to form NPs. While a large number of microbial species are proficientin providing metal NPs, the mechanism of synthesis of NPs is actually important. Due to expanded use of chemical pesticides and fungicides, there is expeditive accumulation in ecotoxicity (Chen et al., 2012; Vu et al., 2015) and leads to resistance improvement in plant pathogenic microbes (Zhavakhiya et al., 2012; Alghuthaymi et al., 2015). The possible solution of the problem is use of biological control of plant pathogens by employing extracts of the plants or metabolites from microbes. Although biological control methods for the management of phytopathogens have been beneficial, considerable inherent defiance needs to be addressed (Frampton et al., 2012). Biosynthesis of selenium, gold, silver, platinum, gold, silica, zirconium, zinc oxide, copper, titanium, chitosan and magnetite NPs by fungi, bacteria, viruses, and yeast have been reported (Narayan et al., 2010). Silver nanoparticles (AgNPs) have become one of the most commonly used nanomaterials in consumer products (104 out of 502 nano products surveyed by Maynard et al., 2005).

The exact mechanism by which Ag NPs destroy and prevent fungal pathogen growth is not well studied. There are many accessible mechanisms discussed by researchers but the exact mechanism has not been annotated. Bacteria are believed to use an enzyme to metabolize oxygen to sustain life. Silver ions cripple the enzyme and stop the metabolization of oxygen. This suffocates the fungi and bacteria, resulting in death (Pubella et al., 2004). Fungal enzymes collaborate with metal ions and reduce to form NPs. The kinetics of the reaction has been studied using UV spectroscopy and was further characterized by X-ray diffraction (XRD), energy dispersive X-ray (EDX) analysis and high-resolution transmission electron microscopy (TEM). The mycosynthesis of metal nanoparticles is the adoption of fungi in nanotechnology for the synthesis of nanoparticles (Rai et al., 2009). The capability of filamentous fungi to grow on readily available and inexpensive substrates, as well as their ability to produce a wide range of commercially interesting metabolites have attracted considerable interest to exploit them as production microorganisms in biotechnology (Dhillon et al., 2012). Preliminary studies show the potential of nano materials in improving seed germination and growth, plant protection, pathogen detection and pesticide/herbicide residue detection (Bhainsa et al., 2006).

Here, we have focused on the reported attempts of using nanoparticles as antifungal, antibacterial, herbicide, pesticides, and carriers of conventional pesticides. Considering using nanoparticles in agriculture, one must remember potential adverse effects; 
therefore phytotoxicity of nanoparticles will also be briefly discussed. We have focused only on the application of myconanoparticles in agriculture, in its most essential part i.e. phytopathogen management. The main technical data from all the literature reviewed is presented in table 1

\section{Synthesis of myconanoparticles}

The use of fungi in producing metallic nanoparticles has received significant interest as they offer certain advantages over the use of bacteria for the synthesis of nanoparticles (Fig. 1). Fungi are excellent secretors of protein as compare to bacteria which lead to more yield of nanoparticles. Silver nanoparticles creation has been the center of research by the scientific association so AgNPs have abundantly conceivable in several industries like antimicrobials and electronics (Nikolas et al., 2014).Several fungal strains have been applied as the brilliant capability for NPs fabrication, for example, Trichoderma, Fusarium, Aspergillus, Verticillium, and Pencillium. Different fungal species are a capable claimant for the creation of nanoparticles both intraas well as extracellular. The advanced methods for the controlled synthesis of nanoparticles of well-defined size shape and proportion is a specific confrontation. Fungi have a number of benefits for NPs synthesis in affiliation to other microorganism and plant material. The application of fungi in the synthesis of NPs is potentially crucial since they produce ample abundance of enzymes and are easy to grasp in the laboratory (Mandal et al., 2006). Since the nanoparticles are synthesized outside the cell, they are apparent to purify and can be directly used in various applications (Mukharjee et al., 2008) Fungal mycelia mesh can bear flow pressure and other conditions in bioreactors or other chambers as correlate to plant material or bacteria (Narayan et al., 2006). Most fungi have a high tolerance towards metals and a high wall-binding capability, as well as intracellular metal uptake capabilities.

\section{Synthesis of nanoparticles by Trichoderma}

The shape and size of biogenic nanoparticles depend upon the biological species involve (Shankar et al., 2003).Silver nanoparticles were synthesized by the bio-control agent, Trichoderma asperellum, with a size range of 13-18 nm with well-defined morphology and presence stable for several months (Gaikward et al., 2013). Some Trichoderma species namely $T$. asperellum, $T$. harzianum, $T$. longibrachiatum, T. pseudokoningii and $T$. virens were selected for the synthesis of silver nanoparticles and these nanoparticles were found single or aggregated with round and uniform shape and a size of 8-60 nm (Devi et $a l ., 2013)$. The selenium nanoparticles were synthesized with $25 \mathrm{mM}$ sodium selenite using culture filtrate, cell lysate and crude cell wall of different Trichoderma spp. (T. asperllum, T. atrovirie, T. harzianum, $T$. virens, $T$. longibrachiatum and $T$. brevicompactrum) Obtained hexagonal, near spherical and irregular shape (Nandini et al., 2017 and Yadav et al., 2018).

\section{Synthesis of nanoparticles by Fusarium}

Screening of various Fusarium sp. for the collection of potential species has been sort out (Dias et al., 2002). Several authors and researchers reported that Fusarium synthesizes the smallest size of silver nanoparticles (Ahmad et al., 2003). Some strains of Fusarium oxysporum can achieve the extracellular fabrication of silver nanoparticles with the help of nitrate-dependent reductase enzyme and a shuttle quinone extracellular pathway (Balaji et al., 2009). The enzyme nitrate reductase might be responsible for the reduction of silver ions (Duran et al., 2005). Pure AgNPs were synthesized at a size range of 5-15 nm. A strain of $F$. oxysporum sp. 
lycopersici was screened and successfully produced inter- and extracellular platinum nanoparticles (Duran et al., 2010. and Khosravi et al., 2009). The extracellular synthesis production of metal NPs by numerous strains of the fungus $F$. oxysporum was reported (Ingle et al., 2008).

\section{Synthesis of the nanoparticle by Aspergillus}

The synthesis of silver nanoparticles by Aspergillus fumigates was proved using XRD and TEM analysis. The XRD spectrum indicated intense peaks in consent with the Bragg reflections of crystalline silver. TEM micrograph of nanoparticles showed variable shape with the majority of them spherical with some triangular form with a size range of 5-25 nm (Bhainsa and D'Souza 2006). Endophytic fungus Aspergillus clavatus effectively synthesized silver nanoparticles with spherical and hexagonal shape (Verma et al., 2010).

\section{Factors affecting synthesis of myconanoparticles}

Several studies revealed that there are some major parameter which affects mycosynthesis of particle size, shape and monodispersity of nanoparticles viz., temperature, $\mathrm{pH}$, exposure of time to substrate biomass, presence of specific enzyme and substrate concentration (Karbasian et al., 2008) employed response surface methodology to investigate the effect of $\mathrm{pH}$, temperature, agitation rate, incubation time, silver salt concentration and weight of fungal biomass on the formation of silver nanoparticles. They obtained spherical shaped silver nanoparticles $(50 \mathrm{~nm})$ by dipping $F$. oxysporum in silver nitrate (3 mM; pH6.0) solution and incubated at $25^{\circ} \mathrm{C}$ with $180 \mathrm{rpm}$ agitation for $96 \mathrm{~h}$ (Fig. 3).

The influence of metal ion concentration on the synthesis of nanoparticles employing Penicillium fellutanum suggested that high concentration would hamper the formation of nanoparticles. The particle size and monodispersity of the particles diverge from the desire nano size range at high silver ion concentration (Kathiresan et al., 2009). Similar to chemical reaction, the concentrations of reactants decide the reaction extent and affect the particle size and monodispersity. One example is gold nanoparticle synthesis using Verticillium luteoalbum. The results revealed that when $\mathrm{AuCl}_{4}$ - concentration was below500 mg 1-1, the particle size was narrow $(\sim 20 \mathrm{~nm})$ and uniform, however, when the concentration was above this, the particle size increased with concentration of $\mathrm{AuCl}_{4}$, but varied from $50 \mathrm{~nm}$ to several hundred nanometers. In addition, massive particle aggregate was found in the cells (Gericke et al., 2006).

\section{Applications of myconanoparticls in phytopathogen management}

Nanotechnology is a new, fast-developing industry, posing substantial impacts on agriculture and allied sectors that likely will produce myriads of nanostructured materials (Mandal et al., 2006; Garc1'a et al., 2010; Gade et al., 2010). Although, fungus mediated synthesis of nanoparticles and their wide array of applications (Figure 4) have recently attracted the attention of researchers towards myconanotechnology. Some of the prominent applications of nanotechnology in various sectors of agriculture have been described in following sections (Fig. 2).

\section{AgNPs as potent antimicrobial agents}

The new branch of science is nanotechnology help in for the investigating of the various type of antimicrobial substances and its effects of metal NPs. It is a mixture of Ag NPs with amphiphilichyper branched macromolecules reveals an effective antimicrobial surface coating (Retchkiman-Schabes et al., 2006) 
likewise other nanoparticles such as copper, zinc, titanium, magnesium, gold, alginate etc. (Gu et al., 2003; Ahemed et al., 2005) has been tested, but Ag NPs have proved to be most efficient as they have excellent antimicrobial effectiveness against bacteria, viruses and fungi (Gong et al., 2007; Lead etal., 2006). The property of nanoparticles could be change with some soil characteristics mainly pollutants and pathogens (Kim et al., 2012). Recently, the efficacy of AgNPs particles is proved by the in vitro study of nanosilver against 18 plant pathogens were evaluated (Prabhu and Poulose, 2012)

\section{Nanoparticles as a suppresser for fungus}

Various types of food crop diseases cause severe impact on the world economy as well as human health so control is essential. Recently, efforts have been made to develop harmless management methods that pose fewer hazards to humans and animals (Falletta et al., 2008). The use of nano sized AgNPs as antimicrobial agents has been utilized as in the management of plant diseases because it has potentially shown various types of mode of inhibitory action to plant pathogens (Mishra et al., 2014, Park et al., 2006), so it may be possible to use against various types of plant pathogens because it is moderately safer compared to synthetic fungicides, for example- $\mathrm{Ag}-\mathrm{SiO}_{2}$ NPs have a strong antifungal activity against Botrytis cinerea (Oh et al., 2006). The combined application of a fungicide such as fluconazole and Ag NPs are effectively suppress the growth of Phomaglomerata, Phomaherbarum, F. semitectum, Trichoderma sp. and $C$. albicans were evaluated by disc diffusion technique by Gajbhiye et al., 2009.

\section{Boost up plant resistance}

Plants are directly or indirectly influenced by various types of biotic stress such as disease- causing agents like insect-pest, nematodes and other pathogens and as well as abiotic stress such as drought, salinity, heat, flood, etc. which is responsible for the tremendous economic loss. Nowadays, to avoid such type of losses, breeders developed a certain resistance variety of plants against them. Resistance in plants would help in the management of above-mentioned agents to overcome the problem of economic loss. A new branch of science the Nano biotechnology able to improve plant resistance by implying a novel set of procedures using NPs, nanofibres and nano capsules to multiply genes and thus improve plant resistance (McKnight et al., 2003; Rai et al., 2012).

\section{AgNPs as nanopesticides}

Last few years, the Ag base nanopesticides are rapidly developed by the researcher for the management of plant pathogen (Kah and Hofmann, 2014). It is developed as a nanopesticide because it has some antimicrobial property which is proved after application against various types of plant pathogen (Elchiguerra et al., 2005).

However, it is safe or nontoxic to humans, soit becomes to increase the effectiveness of $\mathrm{Ag}$ NPs (Yeo et al., 2003).

The larger surface area-to-volume ratio of $\mathrm{Ag}$ NPs increases their contact with microbes and their ability to permeate (Kim et al., 2008).

The mechanism of Ag NPs based nanopesticides is inhibition of the hyphal growth of plant pathogens such as $R$. solani, $S$. sclerotiorum and $S$. minoretc. and the inhibition of phytopathogens depends on the dose of application of AgNPs (Jo et al., 2009). Similarly Mishra et al., 2016 showed that biosynthesized silver nanoparticles using Stenotrophomoas sp. For management of soilborne and foliar phytopathogens. 
Table.1 Fungi in the synthesis of NPs

\begin{tabular}{|c|c|c|c|}
\hline Fungi & NPs & Shape & References \\
\hline Verticillumsp. & Magnetite & Cubo-octaheral & Bhare et al., (2006) \\
\hline Fusariumoxysporum & $\mathrm{Ag}$ & Multishaped & Kumar et al., (2007a) \\
\hline Trichodermareesei & $\mathrm{Ag}$ & Multishaped & Vahabi et al., (2011) \\
\hline Penicilliumsp. & $\mathrm{Ag}$ & Multishaped & Hemath et al., (2010) \\
\hline Aspergillusniger & $\mathrm{Ag}$ & ND & Gade et al., (2008) \\
\hline Aspergillusfumigatus & $\mathrm{Zn}$ & ND & Tarafdar et al., (2013) \\
\hline T. asperellum & $\mathrm{Ag}$ & ND & Mukherjee et al., (2008) \\
\hline Proteus mirabilis & $\mathrm{Zn}, \mathrm{Au}$ & ND & Samadi et al., (2009) \\
\hline Candida utilis & $\mathrm{Au}, \mathrm{Ag}, \mathrm{Zn}$ & ND & Gericke and Pinches (2006) \\
\hline Alternariaalternata & $\mathrm{Ag}$ & ND & Acharya et al., (2011) \\
\hline Fusariumoxysporum & $\mathrm{Ag}$ & ND & Senapati et al., (2004) \\
\hline Fusariumoxysporum & $\mathrm{Ag}$ & Quasi- Spherical & Ahmad et al., (2002) \\
\hline Phomasorghina & $\mathrm{Ag}$ & Rod & Gade et al., (2011) \\
\hline Fusariumoxysporum & $\mathrm{Ag}$ & Spherical & Duran et al., 2005 \\
\hline Alternariaalternata & $\mathrm{Se}$ & Spherical & Sarkar et al., (2011b) \\
\hline Bipolarisnodulosa & $\mathrm{Ag}$ & Spherical & Saha et al., (2010) \\
\hline Rhodococcusspecies & $\mathrm{Mn}, \mathrm{Ag}$ & Spherical & Ahmad et al., (2003) \\
\hline Verticillium sp. & $\mathrm{Cu}, \mathrm{Zn}$ & Spherical & Ahmad et al., (2004) \\
\hline Neurospora crassa & $\mathrm{Au}, \mathrm{Ag}$ & Spherical & Castro-Longoria et al., (2011) \\
\hline Penicilliumsp. & $\mathrm{Au}$ & Spherical & Du et al., (2011) \\
\hline T. harzianum & $\mathrm{Ag}$, & Spherical & Singh and Balaji (2011) \\
\hline Colletrotrichumsp. & $\mathrm{Au}$ & Spherical & Shankar et al., (2003) \\
\hline Alternariaalternata & $\mathrm{Ag}$ & Spherical & Gajbhiye et al., (2009) \\
\hline Alternariaalternata & $\mathrm{Se}, \mathrm{Au}$ & Spherical & Sarkar et al., (2011) \\
\hline Fusariumoxysporum & Zirconia, Si, Ti & Spherical & Bansal et al., (2005) \\
\hline Fusariumoxysporum & $\mathrm{Ag}$ & Spherical & Duran et al., (2005) \\
\hline Verticillumsp. & $\mathrm{Ag}, \mathrm{Au}$ & Spherical & Mukherjee et al., (2001a) \\
\hline Penicilliumsp. & $\mathrm{Au}$ & Spherical & Zhang et al., (2009) \\
\hline Penicilliumsp. & $\mathrm{Ag}$ & Spherical & Maliszewska et al., (2009) \\
\hline Penicilliumsp. & $\mathrm{Au}$ & Spherical & Du et al., (2011) \\
\hline Phomaglomerata & $\mathrm{Ag}$ & Spherical & Birla et al., (2009) \\
\hline Phomasp. & $\mathrm{Ag}$ & Spherical & Chen et al., (2003) \\
\hline V. Volvacea & $\mathrm{Au}, \mathrm{Ag}$ & Spherical & Philip (2009) \\
\hline Trichodermaviride & $\mathrm{Ag}$ & Spherical, Rod-like & Fayaz et al., (2011) \\
\hline Fusariumoxysporum & $\mathrm{Au}$ & Spherical, Triangle & Mukharjee et al., (2002) \\
\hline S. rolfsii & $\mathrm{Ag}, \mathrm{Zn}$ & Triangle & Narayanan \&Sakthivel(2010) \\
\hline Trichodermasp. & $\mathrm{Au}$ & Triangle, hexagonal & Ahmad et al., (2005) \\
\hline
\end{tabular}


Fig.1 Examples of some major fungal species used for the synthesis of nanoparticles

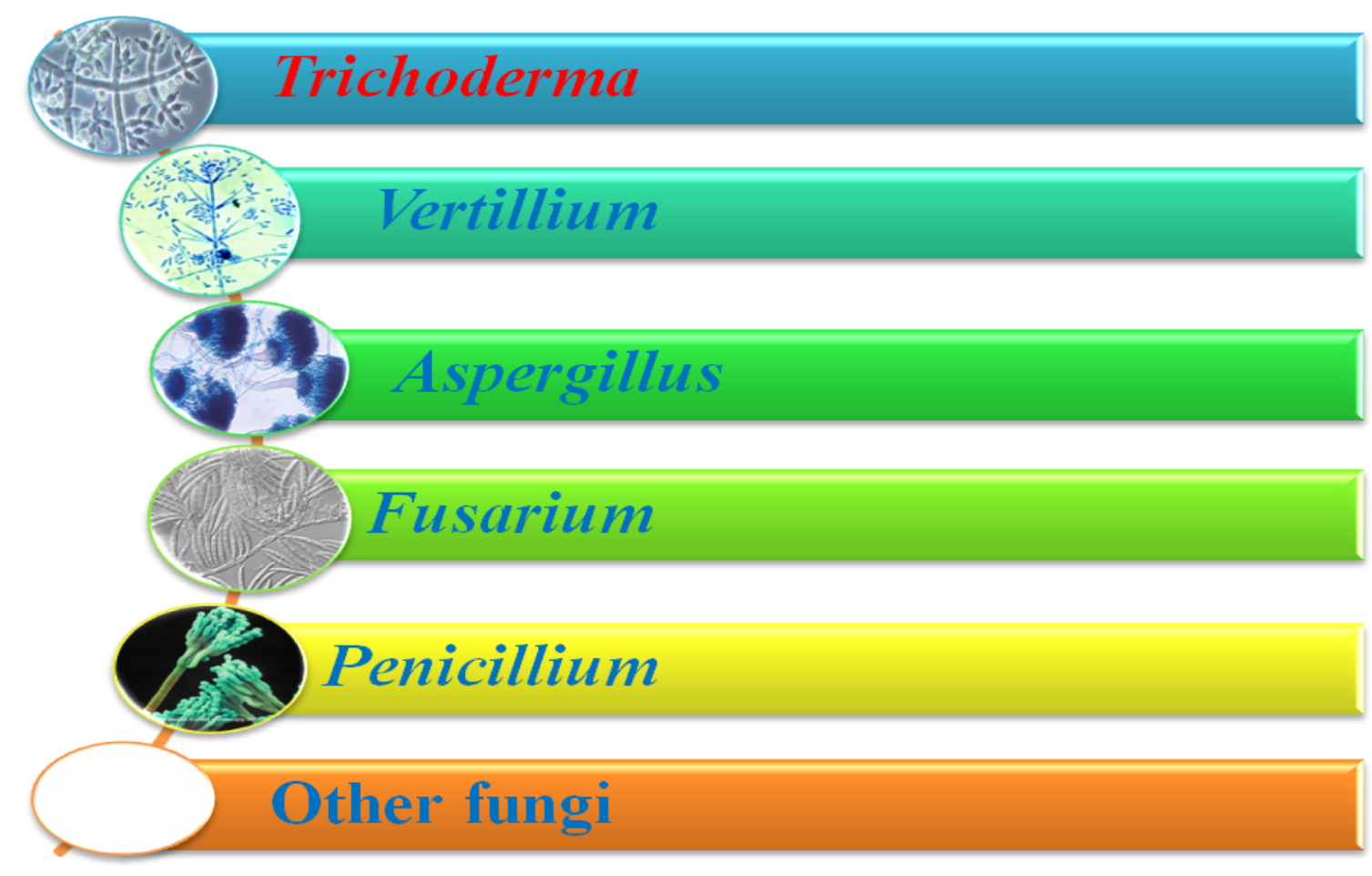

Fig.2 Possible mechanism of action on myconanoparticles (Mishra et al., 2015)

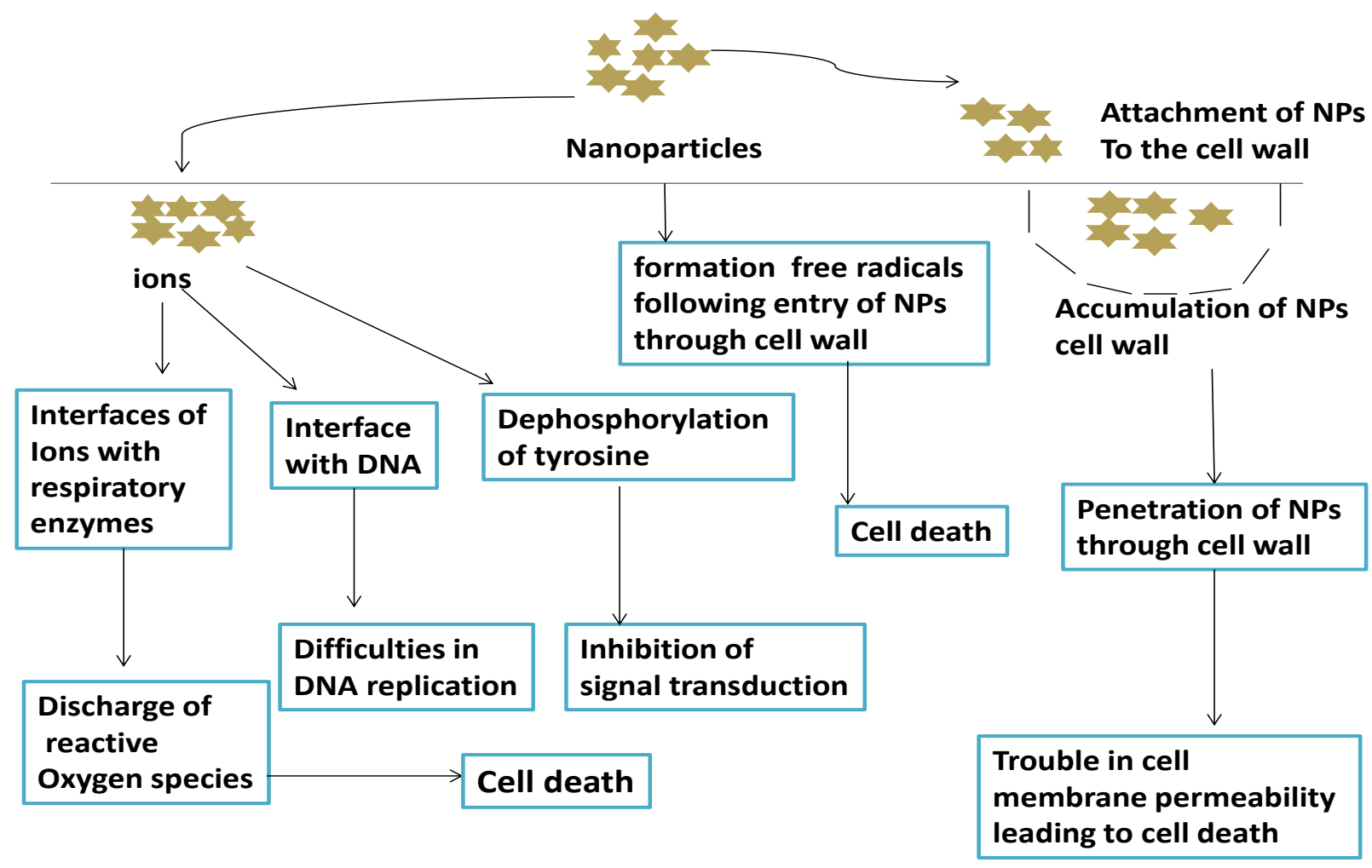


Fig.3 Factors that effect on the synthesis of nanoparticles by fungal biomass

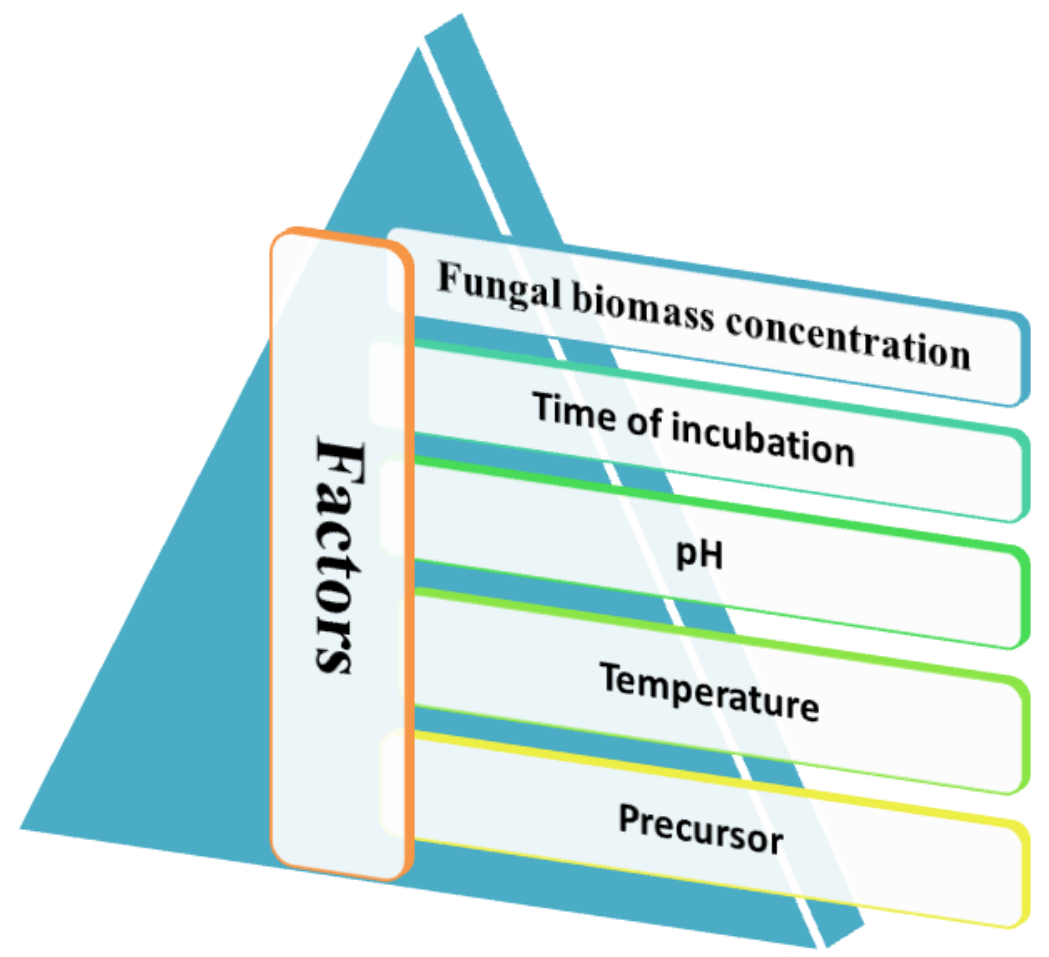

Fig.4 Application of myconanoparticles in plant pathology (Mousa et al., 2014)

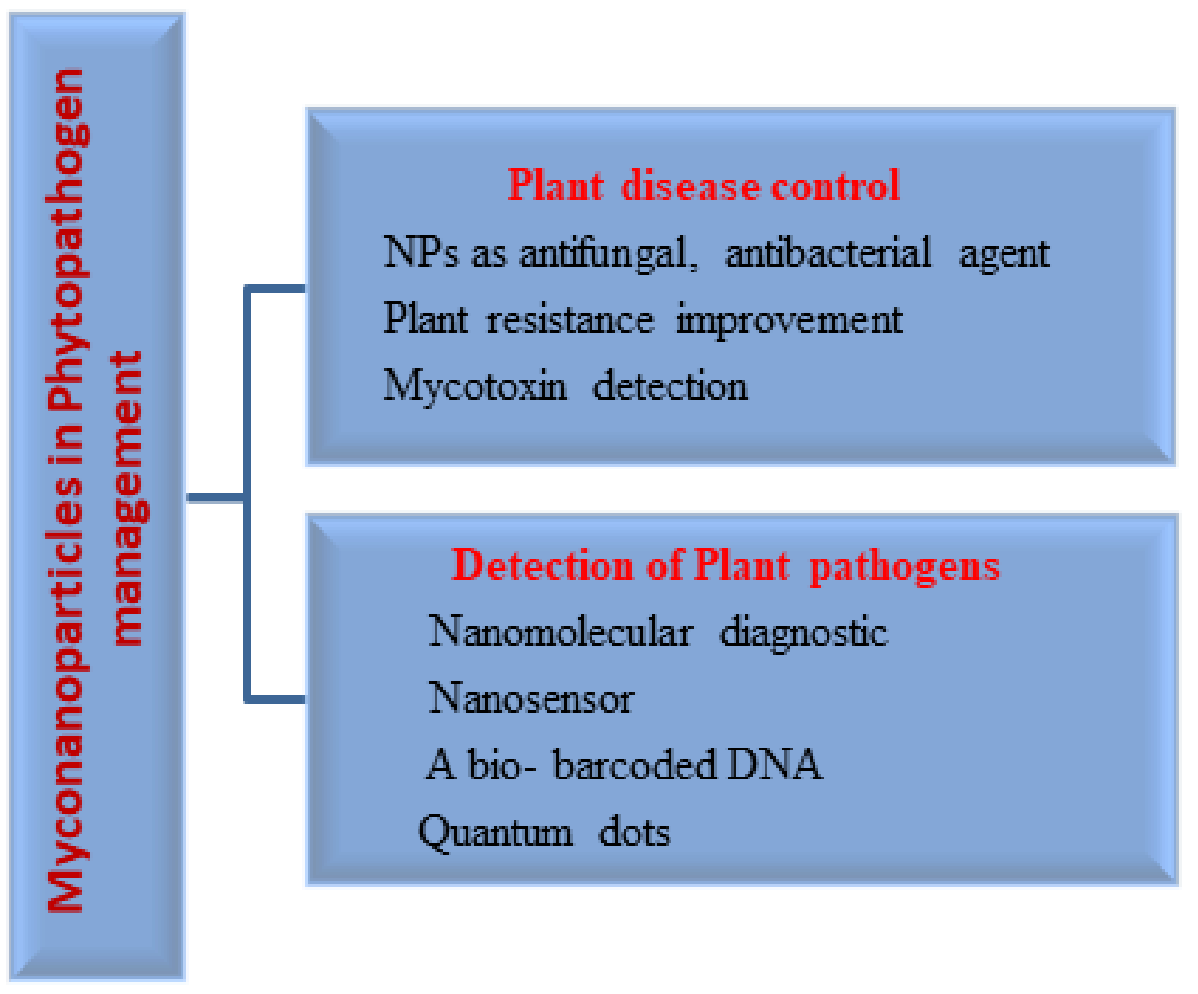




\section{Nanotoxicity}

Nanoparticles have emerged as a useful tool for a wide array of biomedical, consumer and instrumental application, as they have shown a greater specificity with enhanced bioavailability and less detrimental side effects. Despite all these facts, there are certain toxicological effects of the nanoparticles which are harmful to human and agriculture. The study of the toxicity of the nanomaterials or nanoparticles is called as nanotoxicology.

As of the quantum size effects and the large surface area to volume, these materials possess unique characteristics as compared to their larger counterparts which affect their toxicity. Some of the possible hazards include inhalation exposure, pulmonary effects such as inflammation, fibrosis, and carcinogenicity in the animals, skin contact, and the ingestion exposure.

A clear understanding of the nanoparticles and its interaction with the different biological systems at the cellular, molecular, and physiological levels is necessary for the realization of the possible unsafe responses. The nanoparticles exposure affect the mammals and other species adversely at cellular, tissue, and organ level by causing oxidative stress and inflammation. This leads to the altered functioning of the automatic nervous system which in turn results in a rise in respiratory and cardiovascular diseases. The nanoparticles can also enter the blood circulation and disperse to various organs and tissues, thus injuring the organs sensitive to oxidative stress. Overall, the nanoparticles are known to have toxic effects on the functioning of lungs, blood pressure and heart rate alteration, respiratory symptoms, myocardial infarction, arrhythmia, and strokes which causes shorter life expectancy (Kunzli and Tager, 2005).
The generation of ROS is induced by nanoparticles which directly or indirectly plays an important role in the genotoxicity. This oxidative DNA damage is correlated with biological mechanisms that involve mutagenesis, carcinogenesis, and ageingrelated diseases in humans. The oxidative stress is on the many mechanisms that lead to nanotoxicity. The various enzymes that efficiently protect against these harmful biological events are superoxide dismutases (SOD), peroxidases, and catalases. Plants are an essential component in the environment and are critical in the functioning of the ecosystem and supply of food. The nanoparticles exposure in plants also has reported causing abiotic and oxidative stresses at both biochemical and physiological levels.

Nanotoxicity to the higher plants is caused by the bioaccumulation of the metal-based nanoparticles in the plants, distribution of these metal-based nanoparticles in the plant systems, biotransformation of the metal-based nanoparticles inside the plants, phytotoxicity of nanoparticles at physiological and morphological levels, and DNA damage induced by metal-based nanoparticles (Ma $e t$ al., 2015). When the metal-based nanoparticles are once released in the environment, they possess a threat of accumulation at each subsequent trophic level in the food web. There may also be a transportation of these nanoparticles within the food chain through the water and soil systems causing toxicity in both the systems.

Myconanotechnology deals to the promise controlled use of agrochemicals to improve disease resistance, plant growth enhancement and nutrient utilization. Research and development in myconanotechnology can help in management of phytopathogens, another advantage is myconanoparticles are relatively less toxic. Myconanoparticles in conjunction with biotechnology has 
significantly extended the applicability of nanomaterial in crop protection and production. The application of nanomaterials is relatively new in the field of agriculture and it needs further research investigations.

\section{Acknowledgements}

R.N. Yadav is highly thankful to International Rice Research Institute, India for providing funds for this work and also thankful to Department of Mycology and Plant Pathology, Institute of Agricultural sciences, Banaras Hindu University Varanasi-221005, India for providing facilities.

\section{References}

Ahmad A, Mukherjee P, Senapati S, Mandal D, Khan MI, Kumar R, Sastry M. (2003). Extracellular biosynthesis of silver nanoparticles using the fungus Fusarium oxysporum. Colloid Surfaces B. 28: 313-318.

Ahmad Z, Pandey R, Sharma S, Khuller GK (2005). Alginate nanoparticles as antituberculosis drug carriers, formulation development, pharmacokinetics and therapeutic potential. Indian J Chest Dis Allied Sci., 48: 171-176.

Alghuthaymi M. A. Almoammar H. Rai M. Said Galiev E. AbdElsalam K. A. (2015): Myconanoparticles: synthesis and their role in phytopathogens management. Biotechnology and Biotechnological Equipment 29(2): 221-236.

Balaji DS, Basavaraja S, Deshpandeb R, Mahesh DB, Prabhakara BK, Venkataraman A (2009) Extracellular biosynthesis of functionalized silver nanoparticles by strains of Cladosporium cladosporioides fungus. Colloids Surf B: Biointerfaces 68: 8892.
Bhainsa KC, D'Souza SF (2006) Extracellular biosynthesis of silver nanoparticles using the fungus Aspergillus fumigatus. Colloids Surf B: Biointerfaces 47:160164

Bhainsa KC, D'Souza SF (2006). Extracellular biosynthesis of silver nanoparticles using the fungus Aspergillus fumigates. Colloids Surfaces B. 47:160-164.

Bharde A, Rautaray D, Bansal V, Ahmad A, SarkarI, Yusuf SM, Sanyal M, Sastry M. (2006) Extracellular biosynthesis of magnetite using fungi. Small. 2:135141.

Boregowda Nandini, Puttaswamy Hariprasad, Harischandra Sripathy Prakash, Hunthrike Shekhar Shetty \& Nagaraja Geetha. (2017) Trichogenic- selenium nanoparticles enhance disease suppressive ability of Trichoderma against downy mildew disease caused by Sclerospora gramnicola in pearl millet. J Scientific Reports 7: 2612 DOI:10.1038 s41598-017-02737-6

Chen L, Song Y, Tang B, Song X, Yang H, Li B, Zhao Y, Huang C, Han X, Wang S, Li Z, (2015): Aquatic risk assessment of a novel strobilurin fungicide: $A$ microcosm study compared with the species sensitivity distribution approach. Ecotoxicology and Environmental Safety. doi: 10.1016/j.ecoenv.2015.06.027.

Devi TP, Kulanthaivel S, Kamil D, Borah JL, Prabhakaran N, Srinivasa N. (2013) Biosynthesis of silver nanoparticles from Trichoderma species. Indian $\mathrm{J}$ ExpBiol 51:543-547.

Dhillon GS, Brar SK, Kaur S, Verma M. (2012). Green approach for nanoparticle biosynthesis by fungi. Curr Trends Appl. 32:49-73.

Dias MA, Lacerda ICA, Pimentel PF, De Castro HF, Rosa CA. (2002). Removal of heavy metals by an Aspergillus 
terreusstrain immobilized in a polyurethane matrix. Lett. Appl. Microbiol., 34:46-50.

Duran N, Marcato PD, Alves OL, Da Silva JPS, De Souza GIH, Rodrigues, FA, Esposito E. (2010) Ecosystem protection by effluent bioremediation, Silver nanoparticles impregnation in a textile fabrics process. J Nanoparticle Res. 12:285-292.

Elchiguerra JL, Burt JL, Morones JR, Camacho- Bragado A, Gao X, Lara HH, Yacaman MJ (2005). Interaction of silver nanoparticles with HIV-1. J Nanobiotechnol. 3:1-10.

Falletta E, Bonini M, Fratini E, Lo Nostro A, Pesavento G, Becheri A (2008). Clusters of poly (acrylates) and silver nanoparticles: structure and applications for antimicrobial fabrics. J PhysChem C. 112:11758-11766.

Frampton R.A. Pitman A.R. Fineran P.C. (2012): Advances in bacteriophagemediated control of plant pathogens. International Journal of Microbiology doi: $10.1155 / 2012 / 326452$.

Gaikwad S, Birla SS, Ingle AP, Gade AK, Marcato PD, Rai MK, Duran D. Screening of different Fusarium species to select potential species for the synthesis of silver nanoparticles. J BrazChem Soc. 2013; 24:1974- 1982.

Gaikwad S, Birla SS, Ingle AP, Gade AK, Marcato PD, Rai MK, Duran D.(2013) Screening of different Fusarium species to select potential species for the synthesis of silver nanoparticles. J BrazChem Soc. 24:1974-1982.

Gajbhiye M, Kesharwani J, Ingle A, Gade A, Rai M (2009). Fungus mediated synthesis of silver nanoparticles and their activity against pathogenic fungi in combination with fluconazole. Nanomedicine. 5:382-386.
GerickeM, Pinches A (2006) Biological synthesis of metal nanoparticles. Hydrometallurgy 83:132-140

Gong P, Li H, He X, Wang K, Hu J, Tan W (2007). Preparation and antibacterial activity of $\mathrm{Fe}_{3} \mathrm{O}_{4} \mathrm{Ag}$ nanoparticles. Nanotechnology. 18:604-611.

Gu H, Ho PL, Tong E, Wang L, Xu B (2003). Presenting vancomycin on nanoparticles to enhance antimicrobial activities. Nano Lett. 3, 1261-1263.

Jo, YK, Kim BH, Jung G (2009). Antifungal activity of silver ions and nanoparticles on phytopathogenic fungi. Plant Dis. 93: 1037-1043.

Kah M, Hofmann T (2014). Nanopesticide research: current trends and future priorities. Environ Int. 63:224-235.

Karbasian M, Atyabi SM, Siadat SD, Momem SB, Norouzian D (2008) Optimizing nano-silver formation by Fusarium oxysporum (PTCC 5115) employing response surface methodology. Am J AgricBiolSci 3:433-437

Khosravi A, Shojaosadati SA. (2009) Evaluation of silver nanoparticles produced by fungus Fusarium oxysporum. Int J Nanotechnol.6:973983.

Kim KJ, Sung WS, Moon SK, Choi JS, Kim JG, Lee DG (2008). Antifungal effect of silver nanoparticles on dermatophytes. J Microbiol Biotechnol.18:1482-1484.

Kim SW, Kim KS, Lamsal K, Kim Y-J, Kim SB, Jung M, Sim SJ, Kim HS, Chang SJ, Kim JK, Lee YS (2012). An in vitro study of the antifungal effect of silver nanoparticles on oak wilt pathogen Raffaelea sp. J Microbiol. Biotechnol., 19: 760-764.

Künzli, N, Tager, I. B. (2005). Air pollution: from lung to heart. Swiss Med Wkly, 135(47-48), 697-702.

Lead JR, Wilkison KJ (2006). Aquatic colloids and nanoparticles: current 
knowledge and future trends. Environ Chem. 3: 159-171.

Ma C, White J.C, Dhankher O.P, Xing, B (2015). Metal-based nanotoxicity and detoxification pathways in higher plants. Environmental science \& technology, 49(12), 7109-7122.

Mandal D, Bolander ME, Mukhopadhyay D, Sarkar G, Mukherjee P. (2006) The use of microorganisms for the formation of metal nanoparticles and their application. Appl. Microbiol. Biotechnol. 69: 485-492.

Maynard AD, Michelson, E. The Nanotechnology Consumer Product Inventory [Internet] Washington, DC: Woodrow Wilson International Center for Scholars; c2005. Available from: http://www.nanotechprojectorg/44S.

McKnight TE, Melechko AV, Griffin GD, Guillorn MA, Merkulov VI, Serna F, Hensley DK, Doktycz MJ, Lowndes DH, Simpson ML (2003). Intracellular integration of synthetic nanostructures with viable cells for controlled biochemical manipulation. Nanotechnology. 14:551-556.

Mishra S, Singh A, Keswani C, Singh H.B. (2014). Nanotechoology: Exploring potential application in agriculture and its opportunities and constraints. Biotech today, $4: 1$

Mishra S, Singh B.R, Naqvi A.H, Singh H.B. (2016). Potential of biosynthesized silver nanoparticles using Stenotrophomonas sp. BHU-S7 (MTCC5978) for management of soilborne and foliar phytopathogens. Scientific reports 7:45154.

Mohanpuria P, Rana NK, Yadav SK. (2007) Biosynthesis of nanoparticles, technological concepts and future applications. J Nanoparticle Res. 7:9275-9280.

Mukherjee P, Roy M, Mandal BP, Dey GK, Mukherjee PK, Ghatak J, Tyagi AK,
Kale SP. (2008) Green synthesis of highly stabilized nanocrystalline silver particles by a nonpathogenic and agriculturally important fungus Trichoderma asperellum. Nanotechnolology. 19: 075-103.

Narayanan KB, Sakthivel N. (2010). Biological synthesis of metal nanoparticles by microbes. Adv Colloid Interface Sci. 156:1-13.

Nikolas Pantidos and Louis E Horsafall (2014). Biological Synthesis of Metallic Nanoparticles by Bacteria, Fungi, and Plants. Nanomedicine and Nanotechnology 5:5.

Oh SD, Lee S, Choi SH, Lee IS, Lee YM, Chun JH, Park HJ (2006). Synthesis of $\mathrm{Ag}$ and $\mathrm{AgSiO} 2$ nanoparticles by $\mathrm{y}$ irradiation and their antibacterial and antifungal efficiency against Salmonella enteric serovar Typhimurium and Botrytis cinerea. Colloids Surfaces A. 275:228-233.

Park H-J, Kim SH, Kim HJ, Choi S-H (2006). A new composition of nanosized silicasilver for control of various plant diseases plant. Pathol J. 22(3):295302.

Prabhu S. Poulose EK (2012). Silver nanoparticles: mechanism of antimicrobial action, synthesis, medical applications, and toxicity effects. Int Nano Lett. 2:32.

Puebla RA, Dos Santos DS Jr, Aroca RF. (2004) Surface enhanced Raman scattering for ultrasensitive chemical analysis of 1 and 2-naphthalenethiols. Analyst.129:1251-1256.

Rai M, Deshmukh S, Gade A, Elsalam K-A (2012). Strategic nanoparticlesmediated gene transfer in plants and animals a novel approach. Curr Nano. 8:170179.

Rai M, Yadav P, Bridge P, (2009). Gade A. Myconanotechnology (NT), a new and emerging science. In Rai Bridge, editor. 
Applied Mycology. London, UK: CAB International; p. 258-267.

Retchkiman-Schabes PS, Canizal G, BecerraHerrera R, Zorrilla C, Liu HB, Ascencio JA (2006). Biosynthesis and characterization of $\mathrm{Ti} / \mathrm{Ni}$ bimetallic nanoparticles. Opt Mater. 29:9599.

Shankar SS, Ahmad A, Pasricha R, Sastry M. (2003) Bioreduction of chloroaurate ions by geranium leaves and its endophytic fungus yields gold nanoparticles of different shapes. J Mater Chem; 13:1822-1826.

Verma VC, Kharwar RN, Gange AC (2010) Biosynthesis of antimicrobial silver nanoparticles by the endophytic fungus Aspergillus clavatus. Nanomedicine 5:33-40
Verma VC, Singh SK, Solanki R, Prakash S (2011) Biofabrication of anisotropic gold nanotrianglesusing extract of endophytic Aspergillus clavatus as a dual functional reductant and stabilizer. Nanoscale Res Lett 6:16

Yadav R.N, Mishra Divya, Zaidi N.W, Singh. U.S, Singh H.B. (2018). Bio-control efficacy of Trichoderma spp. against two major pathogens of rice (Oryzae sativa L.). International journal of Agriculture, Environment and Biotechnology: 11(3):543-548

Yeo SY, Lee HJ, Jeong SH (2003). Preparation of nanocomposite fibers for permanent antibacterial effect. J Mater Sci.38:21432147.

\section{How to cite this article:}

Yadav, R.N., M.K. Chitara, N.W. Zaidi, A.I. Khan, U.S. Singh and Singh, H.B. 2018. Novel Facets and Challenges in the Management of Phytopathogens Using Myconanoparticles. Int.J.Curr.Microbiol.App.Sci. 7(12): 3296-3308. doi: https://doi.org/10.20546/ijcmas.2018.712.381 